\title{
Jolanta Jabłońska-Bonca
}

\section{Problemy ze spójnością prawa i regulacjami pozaprawnymi a siła sprawcza państwa - zarys tematu}

\section{STRESZCZENIE}

Siła sprawcza państwa w XXI wieku zależy od spójności prawa i rangi regulacji pozaprawnych wielkich korporacji. Współcześnie utrzymanie spójności prawa w pozytywistycznym rozumieniu nie jest możliwe, multicentryczność, wielopoziomowość i siła soft law korporacji prowadzą do przeobrażeń wewnętrznych prawa i zmiany jego funkcji. Ponadto państwo, rezygnując z opiekuńczości i prywatyzując zadania, traci istotne elementy zwierzchnictwa prawnego, terytorialnego i personalnego. Czy oddanie wielu nowych pól aktywności normatywnej oznacza trwałe osłabienie siły sprawczej państwa?

Słowa kluczowe: spójność prawa, pluralizm prawny, soft law, regulacje korporacji międzynarodowych 


\title{
Jolanta Jabłońska-Bonca
}

\section{Challenges with the consistency of laws and regulations and causative force of the state - an outline of the topic}

\begin{abstract}
The causative force of the state in the $21^{\text {st }}$ century depends on the coherence of the law and the importance of non-legal regulations of large corporations. Multi-centricity, multi-level structure and the strength of "soft law" of corporations lead to the transformation of internal law and altering of its function. In addition states give up their welfare and privatise various tasks. They lose the essential elements of the legal, territorial and personal sovereignty. Does giving away numerous normative areas mean that the states do weaken their causative force?
\end{abstract}

Keywords: coherence ofthe law, legal pluralism, "soft law", international corporations regulations 


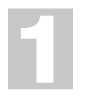

Celem tego tekstu jest wskazanie, że siła sprawcza państwa jest uzależniona od poziomu spójności systemu prawa i autorytetu norm pozaprawnych regulatorów.

Spójność prawa hic et nunc w demokratycznych państwach prawa poddawana jest wielu "testom" weryfikującym zdolności homeostatyczne systemu. Takie zjawiska jak: „multicentryczność” prawa, jego „wielopoziomowość", deterytorializacja państwa prowadzą do istotnych zmian w wykonywaniu zwierzchnictwa prawnego, terytorialnego i personalnego. Zmienia się moc regulatywna norm prawnych, przekształca dostrzegalność wartości uzasadniających obowiązek posłuszeństwa i zmienia sugestywność regulacji.

Z drugiej strony, na skutek wycofywania się państw z realizacji wielu zadań, w opuszczone pola regulacji wkraczają wielkie korporacje gospodarcze i organizacje międzynarodowe, następuje rozwój soft law. Prawo staje się "porowate" - w lukach sadowią się pozaprawne regulacje o rosnącym znaczeniu społecznym. Państwa, prywatyzując zadania, niepostrzeżenie dla obywateli ",zacierają swoje kontury". Notowane jest rozpraszanie władzy, rozpraszanie nadzoru i kontroli między podmioty publiczne i prywatne w sposób, który powoduje, że relacje władzy, podporządkowania i odpowiedzialności stają się w coraz większym stopniu nieprzejrzyste dla jednostki. Jest to zjawisko ze sfery świadomości politycznej i prawnej, mające bezpośredni wpływ na działania i decyzje osób fizycznych i prawnych, na postrzeganie prawa i siły sprawczej państwa.

System prawa w demokratycznym państwie prawa powinien być spójny i pozostawać w równowadze, nie tracąc swojej tożsamości aksjologicznej i formalnej ${ }^{1}$. Tylko takie prawo ma siłę sprawczą i może być skuteczne. Siła sprawcza demokratycznego państwa, rozumiana jako skuteczność finistyczna jego decyzji i działań, zależy m.in. od poziomu spójności prawa.

1 W. Gromski, Autonomia i instrumentalny charakter prawa, Wrocław 2000, s. 40. 
Spójny zbiór ma wbudowane w swoją strukturę mechanizmy i narzędzia zdolne do przywracania homeostazy w przypadkach zdarzających się zakłóceń (w systemie prawa chodzi o usuwanie luk i sprzeczności). Dzięki spójności system jako całość ma (jest postrzegany jako mający) pewne cechy, których nie mają poszczególne elementy systemu. Systemy mogą się przekształcać i oczywiście także rozpadać. Osiągając „efekt masy krytycznej”, mogą „zapadać się pod własnym ciężarem”2.

Spójność systemu prawa służy jego pewności i sile sprawczej państwa. Uznaje się, że prawo pewne, to prawo niesprzeczne, zupełne, uporządkowane, jasne. Takie prawo jest fundamentalną wartością we współczesnych, demokratycznych państwach. „Zasada ochrony zaufania jednostki do państwa i stanowionego przez nie prawa opiera się na pewności prawa, a więc takim zespole cech przysługujących prawu, które zapewniają jednostce bezpieczeństwo prawne; umożliwiają jej decydowanie o swoim postępowaniu w oparciu o pełną znajomość przesłanek działania organów państwowych oraz konsekwencji prawnych, jakie jej działania mogą pociągnąć za sobą - twierdzi Trybunał Konstytucyjny. - Jednostka winna mieć możliwość zarówno określenia konsekwencji poszczególnych zachowań i zdarzeń na gruncie obowiązującego $\mathrm{w}$ danym momencie stanu prawnego, jak też oczekiwać, że prawodawca nie zmieni ich w sposób arbitralny. Bezpieczeństwo prawne jednostki związane z pewnością prawa umożliwia więc przewidywalność działań organów państwa, a także prognozowanie działań własnych"3.

Spójność prawa wyraża się w spójności legislacyjnej oraz związanej z nią spójności sądowej (spójność orzekania o prawie). Spójność sądowa to konieczność rozpatrywania przez sędziów prawa - w pojedynczych przypadkach, jak i w odniesieniu do całej swojej działalności profesjonalnej jako całości, a nie jako oderwanych od siebie decyzji, dla których reszta prawnego i prawniczego zbioru jest tylko tłem ${ }^{4}$. Aby osiągnąć spójność,

\footnotetext{
2 Praca została wykonana w ramach grantu NCN Opus 5 „Prywatna ochrona bezpieczeństwa. »Niepaństwowe prawo""? UMO-2013/09/B/HS5/02671.

3 Wyrok TK SK 19/06 OTK - A- 2007/ 4/37.

4 R. Dworkin, Taking Rights Seriously, London 1977. Inne podejście do spójności mają np. N. MacCormick i 0 . Weinberger, którzy widzą system prawa jako zbiór norm i faktów instytucjonalnych; oryginalną systemową teorię prawa (system autopojetyczny) stworzył m.in. N. Luhmann, zdaniem którego specyfiką systemu prawnego jest to, że komunikuje w swoim obrębie tylko informacje relewantne z punktu widzenia dystynkcji: prawo/bezprawie.
} 
stabilnym przepisom musi więc towarzyszyć utrwalona interpretacja oraz stabilne zasady stosowania prawa.

Rozchwiane i niepewne prawo, prawo wtapiające się w inne decyzje polityczne, osiągające „efekt masy krytycznej”, ,zapadające się pod własnym ciężarem" nadmiaru, obfitości i przeregulowania, może być użyteczne (w jakimś czasie) i służyć sile sprawczej państwa tylko w systemach autorytarnych $^{5}$. Amorfia i destrukcja normatywności spojona mitami politycznymi służy w takich systemach uprzedmiotowieniu społeczeństwa oraz ukrywaniu rzeczywistych celów władzy.

W demokratycznych państwach prawa doktryna, prawodawca i praktyka, dążąc do pewności prawa, zajmują się wspólnie usuwaniem luki sprzeczności w systemach.

Powodami wielu problemów ze spójnością jest zwykła nieostrość systemu prawa. Nieostrość systemu prawa jest pochodną nieuniknionej nieostrości znaczenia reguł oraz nieostrości obowiązywania ${ }^{6}$.

Złożoność systemów prawa i wielokulturowość wielu zachodnich państw wymaga ponadto rozwiązywania m.in. zagadnień recepcji, zapożyczeń, przeszczepów, klonowania, dyfuzji, akulturacji, kopiowania formatów prawnych $^{7}$.

Osiągnięcie spójności, a co za tym idzie stworzenie jednego $\mathrm{z}$ ważnych warunków do utrzymania wysokiej skuteczności decyzji władzy politycznej, administracyjnej i sądowej, utrudniają też zjawiska z zakresu techniki i polityki prawodawczej: defragmentacja prawa polegająca na rozczłonkowaniu materii i delegowaniu kompetencji do regulacji elementów różnym podmiotom, tzw. delegowanie kaskadowe, w tym także do podmiotów pozapaństwowych, co powoduje tworzenie się wielu względnie autonomicznych podsystemów o niejasnym statusie. Problemem są też lawinowe nowelizacje, $\mathrm{tzw}$. resortowe tworzenie prawa oraz $\mathrm{tzw}$. prawodawstwo ad hoc.

W Europie legislacja i stosowanie prawa mają też dodatkowe trudne zadania do wykonania: europejska przestrzeń normatywna łączyła i łączy różne tradycje, ideologie, doktryny, różne siatki pojęciowe i zasady wy-

5 Por. szeroko: J. Jabłońska-Bonca, Prawo w kręgu mitów, Gdańsk 1995.

6 J.Wróblewski, Nieostrość systemu prawa, ,Studia Prawno-Ekonomiczne” 1983, t. XXXI; por. też szeroko: J. Jabłońska-Bonca, Prawo powielaczowe, Gdańsk 1986.

7 Szczegółowo por. T. Stawecki, Konwergencja i dywergencja porzq̨dków prawnych w sferze tworzenia prawa, [w:] 0. Nawrot, S. Sykuna, J. Zajadło (red.), Konwergencja czy dywergencja kultur i systemów prawnych?, Warszawa 2012, s. 24 i nast. 
kładni, różne systematyki prawa, różne podejścia do źródeł prawa, a w szczególności do reguł i zasad prawa oraz do precedensów, różne zasady hierarchii wartości, różne relacje między najwyższymi instancjami sądowymi, różne podejścia do legalizmu. Ta różnorodność, indywidualizm i destrukturalizacja tworzą także rozliczne pola potencjalnych konfliktów. Systemy prawne poszczególnych państw i prawo unijne są rozbudowywane, komplikują się wewnętrznie w sensie formalnym i materialnym, łączą i przenikają w zawiły sposób, a granice prawa poprzez liczne klauzule generalne, zwroty niedookreślone i inne odesłania pozasystemowe stają się coraz mniej szczelne.

Jaki wpływ na siłę sprawczą państw mają powyższe zjawiska związane ze spójnością prawa, a zwłaszcza jego multicentryczność? ${ }^{8}$ Multicentyczność zakłada, że różne ośrodki mogą w sposób wiążący wypełniać swoim działaniem tę samą przestrzeń prawną. Trybunał Konstytucyjny w Polsce pisał o „wieloskładnikowej strukturze systemu prawa (...), na terenie Polski współobowiązują więc podsystemy regulacji prawnych, pochodzące z różnych centrów prawodawczych. Winny one koegzystować na zasadzie obopólnie przyjaznej wykładni i kooperatywnego współstosowania. Okoliczność ta $\mathrm{w}$ innej perspektywie ukazuje potencjalną kolizję norm oraz pierwszeństwo jednego z wyróżnionych systemów" ${ }^{\prime 9}$.

Istotne znaczenie mają zwłaszcza koncepcje ewolucji prawa w stronę systemów autopojetycznych (samoreprodukujących normy prawne, samoodnoszących się, samoorganizujących się i samoregulujących ${ }^{10}$. Rozwijana jest szeroko idea "refleksyjnego", wariantowego opanowywania różnorodności i uzyskiwania spójności z zachowaniem warunków brzegowych ${ }^{11}$.

Spójność prawa, rozumiana w pozytywistyczny sposób, została także poddana doktrynalnej próbie zakwestionowania jej zasad przez filozofię postmodernizmu.

8 E. Łętowska, Multicentryczność współczesnego systemu prawa i jej konsekwencje, „Państwo i Prawo” 2005, nr 4, s. 3-16.

9 Punkt 2 uzasadnienia wyroku z 11 maja 2005 r.

${ }^{10}$ Analiza i ocena koncepcji por. L. Morawski, Główne problemy współczesnej filozofii prawa. Prawo w toku przemian, Warszawa 2003, s. 120 i nast.

${ }^{11}$ G. Teubner, H. Wilke, Dezentrale Kontextstreuerung in Recht intermediarer Verbande, [w:] G. Teubner, H. Wilke, Kontext und Autonomie, "Zeitschrift fur Rechtssoziologie” 1984, vol. 1; G. Teubner, Recht als autopoietisches System, Frankfurt am Main 1989. 
Sędzia europejski ma władzę, lecz jest uwikłany w skomplikowany układ ośrodków legislacji wewnętrznych i ponadnarodowych ${ }^{12}$. Aby wyważyć sprawiedliwe rozstrzygnięcie, musi kierować się przede wszystkim wieloaspektową proporcjonalnością i widzieć poza prawem krajowym także wielosegmentową przestrzeń prawa europejskiego. Ta skomplikowana sytuacja sprawia, że każdy sędzia ma o wiele więcej władzy nad znaczeniami, ale uwikłany jest $\mathrm{w}$ sieci wielopoziomowego systemu regulacji.

Prawo unijne wyraża koncepcję „systemu wielopoziomowego", w którym spójność jest wynikiem uzgodnień wertykalnych (odnoszących się do określonego terytorium) i horyzontalnych (funkcjonalnych). Siła sprawcza pojedynczego państwa mierzona jest inaczej niż przed 50 laty. Unia jest (ma być) zintegrowanym systemem uzgodnieniowym na poziomie regionów, państw i całej wspólnoty. „Charakterystyczny przy tym dla »europejskiego systemu wielopoziomowego« jest (ma być) brak hierarchicznego podporządkowania poszczególnych poziomów działania i decyzyjnych oraz asymetria w posiadanych kompetencjach"13. Ta tendencja to duży problem dla tradycyjnie, pozytywistycznie rozumianej spójności i pewności prawa i duży problem dla państw.

Transformacja prawa, państwa, a nawet koncepcji wojen i bezpieczeństwa to elementy transformacji struktur społecznych i transformacji struktur regulacyjnych „,w jedną globalną sieć informacyjna, co następuje poprzez wchłanianie ich, w wyniku czego wszystko staje się czymś innym niż było. Jest to kryzys wielokierunkowy, tworzący, splątany, wieloczynnikowy, często wewnętrznie sprzeczny proces przyczynowo skutkowy, niejednokrotnie oparty na zależnościach zwrotnych. Wszystko co było, gospodarka, instytucje, kultura, typ tożsamości czy ładu społecznego, musi zostać ponownie określone w relacji do globalnej sieci i poprzez nią"14.

Pilnie potrzebne są więc modele nowych relacji państwo-organizacjeprawo w niejasnej „patchworkowej” perspektywie wielopoziomowej (lokalnej, państwowej, ponadnarodowej, transnarodowej) dla projektowania adekwatnych sposobów tworzenia prawa. Dekompozycja i mała użytecz-

\footnotetext{
12 J. Jabłońska-Bonca, Wymiar sprawiedliwości a przemiany kultury prawnej w Europie, [w:] W. Morawski (red.), Powiqzania zewnętrzne. Modernizacja Polski, Warszawa 2012, s. 296-313.

13 J. Czaputowicz, Rola państwa w Unii Europejskiej, Warszawa 2004.

${ }^{14}$ Pogląd Manuela Castellsa zacytowany w: K. Wielecki, Kryzys i socjologia, Warszawa 2012, s. 299: por. szeroko: M. Castells, Siła tożsamości, Warszawa 2009.
} 
ność poznawcza oraz praktyczna XX-wiecznych wzorów i paradygmatów jest faktem.

Nie tylko spójność wewnętrzna prawa jest problemem. Spójność prawa jest także współcześnie poddana silnej presji z zewnątrz - ze strony innych systemów i źródeł normatywnych. Źródła te są silne; po pierwsze - obejmują obszary normowania sprywatyzowanych zadań państwa, nad którymi kontrola została oddana w ostatnich 30 latach podmiotom prywatnym; po drugie - obejmują zupełnie nowe obszary regulacji wyłaniające się wraz z globalizacja, rewolucją informacyjną i technologiczną. Te zjawiska nie są obojętne dla prawa; powodują otwierania jego granic, entropię prawa, pobudzają dyskusję o równoważnych instytucjonalnych porządkach normatywnych, pluralizmie prawnym i soft law.

Rozmaite zbiory norm pozaprawnych mają coraz poważniejsze znaczenie $\mathrm{w}$ regulacji życia społecznego i gospodarczego na podstawie prawnych odesłań, zwrotów niedookreślonych i klauzul generalnych. Czy ma to znaczenie dla siły państw?

Powodem wzrostu rangi tych norm jest odwrót państw zachodnich od koncepcji państwa opiekuńczego (a co za tym idzie także rezygnacja z bezpośrednich regulacji). Władza państwa rezygnującego z opiekuńczości, „sącząca" się coraz częściej na niejasnych zasadach „poprzez" instytucje prywatne (globalne, ponadpaństwowe i lokalne) w swoistym „kolażu” z elementami etatystycznej, centralistycznej wewnętrznej władzy tradycyjnej, utrudnia przez swoją policentryczność, partycypacyjność, wielopoziomowe zarządzanie i „sieciowość" orientację kto, kiedy i za co odpowiada w przestrzeni publicznej, komu trzeba albo komu warto się podporządkować ${ }^{15}$.

Przyjrzyjmy się bliżej kilku przykładowym zjawiskom z tego zakresu.

W pierwszej kolejności zajmiemy się siłą sprawczą regulacji stanowionych przez wielkie, międzynarodowe korporacje gospodarcze i organizacje międzynarodowe ${ }^{16}$.

\footnotetext{
${ }^{15}$ K. Wielecki, Kryzys..., op. cit., s. 299.

${ }^{16}$ B. Roach, Corporate Power in Global Economy, Medford 2007.
} 
Korporacje poprzez swoje decyzje o lokalizacji produkcji w różnych miejscach przyczyniają się do restrukturyzacji gospodarek poszczególnych państw. Ich strategie mają istotny wpływ na międzynarodowy podział pracy.

Ich akty normatywne oraz regulacje powstające w koordynacji mają społeczną i polityczną siłę równą sile umów międzynarodowych, a czasem mają realną przewagę. Ta siła wynika m.in. z prowadzenia działalności w wielu krajach, czasem z powodu "globalnego mandatu" (wybrana filia działa nie dla rynku lokalnego, ale dla całego świata), z elastyczności organizacyjnej. Wynika z racji posiadanego ogromnego potencjału ekonomicznego, niekiedy znacznie przewyższającego niektóre państwa. Na przykład wartość rynkowa Apple przekroczyła 600 mld dolarów. To znaczy, że „można by za nią kupić 2,14 Grecji"17.

Korporacje produkcyjne, usługowe i finansowe działają w znacznym zakresie niezależnie od sytuacji i interesów państw będących terenem ich ekspansji. Polityka prowadzona na poziomie państwa narodowego staje się faktycznie wyłącznie lokalna, bo nie może rozwiązać żadnych kluczowych problemów o zasięgu globalnym.

Sieć kontaktów, przedsiębiorstw transnarodowych, organizacji międzynarodowych i stowarzyszeń ponad państwami narodowymi kreuje nowe formy współpracy, a najważniejsze decyzje zapadają w gremiach nieformalnych (G8 czy G20). Anthony Giddens twierdził, że państwo, które ma zapewnić sprawność zarządzania, zdolność konkurencji w globalizującym się świecie, równość, zaufanie, poczucie bezpieczeństwa, opiekę - musi to dziś robić zupełnie inaczej niż niegdyś. Jednym z jego fundamentów będzie gospodarka mieszana, która łączy ze sobą elementy regulacji i deregulacji, prywatyzacji i własności prywatnej oraz społecznej, wolności i ograniczeńn ${ }^{18}$. Czy miał rację?

Deregulacja i prywatyzacja prowadzą do istotnych zmian w wykonywaniu zwierzchnictwa terytorialnego i personalnego. Zjawisko określane jest jako „deterytorializacja” państwa i utrata „nieprzenikliwości” - swobodny przepływ osób, towarów i usług, zanikanie granic wewnętrznych (UE), obywatele nie są już poddanymi władzy państwa, lecz mają prawa uniwersalne, poddane międzynarodowej kontroli. Prawo petycji w Unii

17 0. Szewczyk, Odpowiedzialność,,,Wprost”, 1.08.2012, dane za magazynem „,Mac Format”.

${ }^{18}$ A. Giddens, Trzecia droga. Odnowa socjaldemokracji, Warszawa 1999, s. 99. 
Europejskiej, Europejski Trybunał Praw Człowieka, ochrona przed dyskryminacją - przynajmniej w Europie przeobrażają sytuację.

Pojawiły się także poglądy, że kierunek zmian w życiu społecznym wcale nie jest przesądzony, nie jest wykluczone ryzyko dryfowania zachodnich systemów politycznych w stronę tak zwanych demokratur. Ten neologizm opisuje sytuację, w której funkcjonują fasadowe struktury demokratyczne, ale faktyczną władzę sprawują ponadnarodowe korporacje infiltrujące, korumpujące i uzależniające od siebie wszystkie główne struktury państwa. Państwo usuwa się z areny gospodarczej, przyszłość jest w rękach nieuchwytnych globalnych sił gospodarczych.

W otoczeniu prawa wewnętrznego, międzynarodowego i unijnego powstają i obowiązują liczne poważne regulacje tychże podmiotów. Nie mają legitymacji demokratycznej jak prawo, nie stoi za nimi aparat przymusu państwa. Ich moc dyrektywalna wsparta jest o słuszność, użyteczność albo racjonalność ekonomiczną oraz aktualność rozwiązań. Regulacje korporacji są wymuszane przez potrzebę pilnego uregulowania nowych zjawisk globalizacyjnych ${ }^{19}$. Bywają nazywane paraprawem.

Są to akty działające zewnętrznie, regulujące wprost albo odblaskowo istotne społecznie prawa i obowiązki użytkowników i klientów korporacji. Są to regulacje kwalifikowane tradycyjnie (pozytywistycznie) jako pozasystemowe, często jednak obowiązek ich przestrzegania wynika z prawa (opierają się na odesłaniach o różnym charakterze prawnym), a dotyczą też adresatów nie podporządkowanych służbowo firmom.

Prawodawcy krajowi, związani skomplikowanymi procedurami legislacyjnymi, nie chcą albo nie są w stanie reagować tak mobilnie jak podmioty prywatne ${ }^{20}$. Pola regulacyjne obejmują szybciej od państw wielkie korporacje. Jest faktem, że legitymizowane formalnie struktury prawodawcze państw i organizacji międzynarodowych, jeżeli w ogóle decydują się na

\footnotetext{
${ }^{19}$ Przykładem mogą być powszechnie stosowane wytyczne ISDA - International Swaps and Derivatives Association inc. albo semiperatywny autonomiczny porządek normatywny, w którym decyduje ICANN - Internetowa Korporacja ds. Rozdziału Nazw i Adresów ID. Jest to prywatna agencja pożytku publicznego. Wykształcił się też autonomiczny system arbitrażu i polityka jednolitego rozstrzygania konfliktów.

20 J. Jabłońska-Bonca, Tempus Fugit, ,'Studies in the Philosophy of Law" 2014, nr 8, s. 58.
} 
podjęcie kroków regulacyjnych w wielu nowych obszarach, to dopiero wtedy, gdy określone zjawiska (np. w cyberprzestrzeni) mają już charakter stosunkowo trwały, nie zaś wtedy, gdy one powstają.

Regulacje paraprawne zalicza się na ogół do kategorii soft law, a często nazywa także lex ferenda. Soft law, czyli "miękkie prawo", nie jest formalnie wiążące $\mathrm{z}$ woli państwa, a lex ferenda to takie regulacje z obszaru soft law, które mają szansę na przekształcenie w hard law.

Przykładami mogą być obszary norm zwane: lex sportiva, lex informatica czy prywatne normy ochrony bezpieczeństwa.

Kosmopolityczne rozumienie regulacji dotyczy np. tzw. lex sportiva ${ }^{21}$. Tak też uzasadniane są wprost niektóre regulacje międzynarodowych sportowych organizacji. Autonomię regulacyjną zadeklarowało jednoznacznie w 1992 roku Międzynarodowe Stowarzyszenie Federacji Lekkoatletycznych (IAAF): „Sądy stwarzają nam mnóstwo problemów w zwalczaniu dopingu, ale my mówimy, że w najmniejszym stopniu nie liczymy się z nimi, gdyż mamy własne reguły, które są nadrzędne"22.

Podobnie uzasadnia się także próby budowania autonomicznego porządku normatywnego Internetu (w zakresie ochrony znaków towarowych, wolności ekspresji i dóbr osobistych) ${ }^{23}$. Legitymacja Internetowej Korporacji ds. Rozdziału Nazw i Adresów (ICANN) nie jest legalistyczna i demokratyczna, a charyzmatyczna, profesjonalistyczna i efektywnościowa ${ }^{24}$. ICANN pełni funkcję internetowego nawigatora i kartografa, jest prywatną organizacją pożytku publicznego.

Podobne zjawiska zachodzą w obszarze prywatnej ochrony bezpieczeństwa. Na przykład Międzynarodowy kodeks postępowania dla prywatnych dostawców usług bezpieczeństwa ustanawia „globalne standardy dla prywatnego sektora bezpieczeństwa" ${ }^{25}$. Tzw. standardy globalne wynikające z własnego zobowiązania podejmowanego w stosunku do wszystkich

\footnotetext{
21 Por. pr. zbior. red. A. Szwarc, Kompatybilność pozaprawnych regulacji sportowych z regulacjami prawnymi, Poznań 2014.

${ }^{22}$ Cyt. za: K. Foster, Is there a global sports law? „,Entertainment Law” spring 2003, vol. 2, no. 1, s. 1.

${ }^{23}$ K. Dobrzeniecki, Autonomiczne prawo cyberprzestrzeni: mit czy rzeczywistość?, [w:] 0. Bogucki, S. Czepita (red.), System prawny a porzqdek prawny, Szczecin 2008; idem, Lex informatica, Toruń 2008.

24 Internet Corporation for Assigned Names and Numbers.

25 Bliżej por. J. Jabłońska-Bonca, Policentrycznośćźródeł norm w zakresie bezpieczeństwa obywateli. Problem czy margines?, [w:] pr. zbior. red. S. Lewandowski, H. Machińska, J. Petzel, Prawo, język, logika, Warszawa 2013, s. 59.
} 
(niepodporządkowanych organizacyjnie i służbowo) uczestników obrotu są coraz ważniejszym źródłem norm. Korporacja lub organizacja pozarządowa zobowiązuje się wprowadzać we wszystkich jurysdykcjach, w których operuje, najwyższe standardy działalności obowiązujące w innej jurysdykcji ${ }^{26}$. Jeśli w jednym z państw obowiązują najwyższe standardy, wynikające np. z przepisów prawa danego państwa, to działalność globalnej korporacji lub organizacji pozarządowej będzie dostosowywana również we wszystkich innych jurysdykcjach do tych najwyższych standardów, niezależnie od krajowych norm i panującej kultury prawnej. Siła sprawcza państwa o zasięgu wewnętrznym nie ma większego znaczenia. $W$ ten sposób kształtują się w XXI wieku oryginalne pisane normy pozaprawne o zasięgu globalnym.

W sposób zamierzony dochodzi więc do autonomicznej regulacji ważnych podsystemów społecznych, a prawo pozostaje daleko w tyle. Czy ma to wpływ na prestiż państwa?

Czy zjawisko to można nazwać „pluralizmem prawnym”, odchodząc od tradycyjnego pozytywistycznego powiązania prawa i państwa w XXI wie$\mathrm{ku} ?^{27}$

John Griffiths w 1987 roku w tekście What is legal pluralism? 1986 r. pisał: „pluralizm prawny jest faktem, a centralizm prawny mitem, postulatem i ideologią". Twierdził, że należy zaaprobować autonomię spontanicznie powstających porządków prawnych, a pluralizm prawny jest „współbieżny" z pluralizmem społecznym" ${ }^{28}$. "Mit centralizmu prawnego" to fałszywe wierzenie, że prawo tworzy tylko państwo. Gdyby Griffiths miał rację, także centralna siła sprawcza państwa jako prawotwórcy byłaby mitem.

Zajmujący się tym zagadnieniem badacze przypominają że $w$ historii policentryczność podmiotów regulujących życie społeczne była norma,

\footnotetext{
${ }^{26}$ Por szerzej: T. Braun, Charakterystyka zadań i normy tworzone przez funkcję compliance w bankowości - wyzwania rynków regulowanych, ,"Krytyka prawa” 2014, nr 6 (w druku).

27 M.A. Torre, Legal pluralism as evolutionary achievment of community law,,, Ratio luris" 1999, vol. 12, no. 2, s. 182-194; por. szeroko: J. Winczorek, Pluralizm prawny wczoraj i dziś. Kilka uwag o ewolucji pojęcia, [w:] D. Budnikowski, K. Dobrzeniecki (red.), Pluralizm prawny, Toruń 2009, s. 12-35.
}

${ }^{28}$ Za J. Winczorek, Pluralizm..., op. cit., s. 23. 
dominacja prawa pochodzącego od państwa nie była w świadomości społecznej tak wyraźna i przytaczają przykłady obszarów powszechnego działania prawa kościelnego, prawa gildii, miejscowych systemów prawnych w Imperium Rzymskim ${ }^{29}$. Dominacja prawa pochodzącego od państwa narodowego w świadomości społecznej w czasach nowożytnych obejmuje około 200 lat.

Być może lepszą koncepcją opisującą tę sytuację jest „interlegalność”. Bonaventura de Sousy Santos, twórca koncepcji „,interlegalności”, twierdzi, że prawo składa się z wielu nakładających się na siebie obszarów, które można uporządkować za pomocą metafory mapy. Zjawisko to wiąże się z ograniczaniem działalności prawotwórczej państwa wycofującego się z wielu obszarów. Opuszczoną przestrzeń zajmują spontanicznie powstające, niepaństwowe porządki prawne. Nie są wyraźnie wyodrębnione, nie mają ostrych granic systemowych. Wykorzystanie „porowatości” współczesnego prawa może, zdaniem Santosa, zostać wykorzystane dla zrealizowania projektu „oddolnej globalizacji”, możliwej bez jednego centrum decyzyjnego ${ }^{30}$. Santos wiąże więc swoją koncepcję utraty spójności przez prawo w pozytywistycznym rozumieniu ze zmianą roli państwa, ze słabnięciem jego siły sprawczej.

Siła sprawcza państwa, oddającego współcześnie nowe pola regulacyjne podmiotom prywatnym, mogłaby być utrzymana, gdyby działał skuteczny nadzór publiczny. Ten jednak nie jest często w ogóle zorganizowany prawnie i faktycznie albo jest kruchy i nieszczelny. W szczególności jest dyskusyjne, czy współcześnie owe pozaprawne rozwiązania, tworzone jakoby z powodu ich użyteczności, służą zawsze interesowi publicznemu lub interesowi państwa, a nawet, czy zawsze służą całemu podsystemowi społecznemu, dla którego powstały (np. dla sportu) na równych zasadach. Niewykluczone jest, że mogą tworzyć się prywatne monopole normatywne niesłużące dobru wspólnemu, państwu albo regulowanemu środowisku. Silne korporacje i organizacje tworzą je często głównie dla siebie, dla własnych partykularnych interesów, eliminując wpływ słabszych podmiotów z regulowanego środowiska na ich treść. Władze korporacji nie są przecież zorientowane na osiąganie celów w długich horyzontach czasowych i nie

\footnotetext{
${ }^{29}$ Podobnie prywatne wojska i prawo do prywatnego odwetu były przejawem policentryczności podejścia do legalnego użycia siły.

${ }^{30}$ B. de Sousa Santos, Toward a New Legal Common sense. Law, Globalization, And Emancipation, London 2002.
} 
są powiązane, tak jak władze państwa, z terytorium i ludnością. Zastąpienie prawnej regulacji regulacją prywatną prowadzić może też do utraty poczucia bezpieczeństwa obywateli, ponieważ tracą oparcie w państwie, a nie uzyskują na ogół podobnego oparcia w normach korporacji.

Sieci korporacji transnarodowych nie realizują aksjologii państw, a działają „ponad” państwami, tworzą oderwane od państw globalne układy i aksjologie. Prawo wewnętrzne państw nie nadąża za tymi przeobrażeniami, siła sprawcza państw nie sięga skutecznie do tego obszaru ${ }^{31}$.

Regulacje pozaprawne wielkich korporacji i międzynarodowych organizacji są adresowane nie tylko do pracowników i innych podmiotów pozostających w bezpośredniej relacji z tymi korporacjami, ale często działają "odblaskowo" - wyznaczają obowiązki znacznie szerszej kategorii adresatów, niepodporządkowanych formalnie korporacjom ${ }^{32}$. Szeroki zasięg tych unormowań wynika między innymi z tego, że podmioty te prowadzą równocześnie działalność w kilkudziesięciu jurysdykcjach, ich pracownicy to setki tysięcy, a klienci to nawet miliony osób.

Legitymacja korporacji dla regulacji zewnętrznych nie ma oczywiście charakteru demokratycznego, wynika natomiast z posiadanej władzy ekonomicznej, głównie opartej na własności, ponadto z autorytetu środowiskowego, wysokiego profesjonalizmu i specjalizacji, czasem z pozycji monopolisty. Liczą się w tym przypadku głównie: wartość ekonomiczna reguł pozaprawnych, ich racjonalność ekonomiczna, użyteczność regulacji dla grupy interesów albo ich słuszność ceniona z powodu doświadczeń zbiorowości. Ważna jest siła gospodarcza pozaprawnych autorytetów normatywnych.

Adresatami wielu aktów są nie tylko pracownicy tych firm, ale także klienci i osoby postronne, np. odwiedzające obiekty użyteczności publicznej, parki, stadiony, poczty, centra handlowe, niemające żadnych umów z korporacjami, a często w ogóle niemające i niemogące mieć świadomości, że mogą znaleźć się w orbicie działania takich norm. Choć regulacje pochodzą od prywatnych firm i nie są wydane na podstawie upoważnień ustawowych i odesłań pozasystemowych, mają czasem zastosowanie do osób

\footnotetext{
${ }^{31}$ Na przykład: Czy po sprywatyzowaniu cały dotychczasowy porządek publiczny w dotychczasowym kształcie musi być respektowany przez nowy podmiot? Czy dobro publiczne sprywatyzowane wyklucza dostęp do informacji publicznej? Czy spory związane z zadaniami sprywatyzowanymi powinny być rozstrzygane przez sądy administracyjne? Jakie są konsekwencje tych prywatyzacji dla praw jednostki?

32 Por. np. J. Jabłońska-Bonca, Policentryczność..., op. cit., s. 59-75.
} 
niepodporządkowanych. Określają ich stanowcze prawa i obowiązki (ale jakie? - pozaprawne? nieprawne?), jednak bez jakiejkolwiek wiedzy jednostek o takiej regulacji (nie działa tu zasada ignorantia iuris nocet, bo nie jest to prawo). Na przykład: Czy w Polsce można otrzymać od firmy monitorującej budynek mieszkalny film z monitoringu z własnym wizerunkiem nagranym przez tę firmę? Czy wymaga to wyroku sądowego? Czy można wnieść w Polsce parasol na stadion? Czy można skutecznie i legalnie w świetle prawa międzynarodowego odzyskać broń od pracownika firmy ochrony podczas konfliktu zbrojnego (odebrać mu broń jak jeńcowi)?

Podobną kategorię ważnych pozaprawnych regulacji o niejasnym statusie tworzą regulacje ostrożnościowe wydawane przez różne, istotne politycznie i gospodarczo podmioty administracji publicznej, niedysponujące w państwach kompetencjami prawotwórczymi, a nazywane w praktyce działalności gospodarczej „regulatorami” poszczególnych rynków ${ }^{33}$. Głównie są to normy o zadaniach prewencyjnych, zapobiegające zachowaniom niepożądanym ${ }^{34}$.

Do nowych zjawisk ograniczających siłę sprawczą państw, związanych z globalizacją i poszukiwaniem spójności ponad granicami, należy także transgraniczna skuteczność przepisów krajowych w działalności korporacji. Chodzi o wprowadzenie do porządku prawnego jednego z państw takich przepisów, które zobowiązują podmioty z tego państwa do przestrzegania określonych reguł oraz do zapewnienia, że te same obowiązki będą wykonywane przez inne podmioty tej grupy, także w innych krajach, ewentualnie też przez dostawców usług, a nawet klientów.

Autonomiczne, legitymizowane profesjonalnie regulacje podsystemów normatywnych, tworzone intencjonalnie, mające status publiczny często połączone w systemem jednolitej, międzynarodowej, polubownej jurysdykcji, odwołują się do dyskusyjnego założenia, że można wyodrębnić wspólny fundament aksjologiczny ich globalnych zasad. Te zasady dopuszczają możliwość przyjęcia koncepcji istnienia globalnego prawa bez państwa, rozumianego szeroko, $\mathrm{w}$ duchu pluralizmu.

${ }_{33}$ M. Bączyk, E. Fojcik-Mastalska, L. Góral, J. Pisuliński, W. Pyzioł, Prawo bankowe. Komentarz, Warszawa 2003, s. 509 i nast.

34 Tworzone są na poziomie międzynarodowym, unijnym i krajowym. Na przykład bankowe normy ostrożnościowe tworzy: Bazylejski Komitet ds. Nadzoru Bankowego, Komitet Europejskich Organów Nadzoru Bankowego, w Polsce - Komisja Nadzoru Finansowego. Por. szeroko: M. Olszak, Bankowe normy ostrożnościowe, Białystok 2011. 


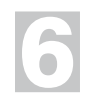

Globalizacja oraz rozszerzanie pól regulacji przez państwa i jednoczesne zlecanie albo delegowanie wielu zadań do organizacji pozarządowych, ponadnarodowych, korporacji gospodarczych itd., a więc w dół, w bok i do góry struktury władzy, powoduje rozpraszanie różnych form kontroli, nadzoru i odpowiedzialności między rozmaite podmioty. Ma to wpływ na siłę sprawczą państw. Coraz większe „otwory” między „węzłami” w rozrastającej się ",sieci” prawa nie pozostają puste. Wypełniają je rozmaite normy pozaprawne. Nie są też powszechnie dostępne, nie powstają pod nadzorem demokratycznych organów przedstawicielskich. Są wprawdzie często tworzone we współpracy z państwem (np. są uzgadniane), ale obywatel (jednostka), trafiając na ich działanie w obszarze sprywatyzowanych zadań, poprzednio należących do państwa, na ogół nie rozumie, kto i w jakim zakresie teraz ma nad nim władzę. „Oblicze” prawa widziane z bliska staje się wobec tego mgliste, a przez "zasłony” norm prywatnych organizacji, które przejmują obecnie od państwa różne zadania, staje się często zupełnie niewyraźne.

Wiele centrów normowania, publicznych, społecznych i prywatnych, standaryzuje, penetruje, ocenia, robi audyty, nadzoruje, ewidencjonuje w ramach zadań zleconych, partnerstwa publiczno-prywatnego albo z powodu dokonanej prywatyzacji.

Nowa wielowymiarowość i wielopodmiotowość norm pochodzących z różnych źródeł państwowych i pozarządowych pozbawia obywatela twardych, tradycyjnych, kulturowo zakorzenionych punktów odniesienia. Małe narracje pofragmentaryzowanego życia są formatowane $\mathrm{z}$ niejasnych powodów przez coraz liczniejsze podmioty. To prowadzić może do wykluczeń osób niezorientowanych w strukturze publiczno-prywatnej władzy XXI wieku.

Dla adresata nie ma na ogół poważnego znaczenia, kto dokładnie jest normodawca, ale czy czuje, że są to normy mające ważną legitymację, należy tych norm przestrzegać oraz jakie za ich nieprzestrzeganie grożą sankcje?

Jeśli za naruszenie regulaminu zachowania na stadionie albo w cywilnym porcie lotniczym w Polsce - oba typy aktów stanowią podmioty prywatne i oczywiście nie należą do kategorii konstytucyjnej źródeł prawa - grożą sankcje wynikające z ustaw (a tak jest w Polsce w ustawie o organizacji imprez masowych i w prawie lotniczym) i możliwość orzeczenia sądu zasądzającego 
grzywnę albo zastępczo areszt - to osoba bez wykształcenia prawniczego sądzi, że to jest prawo. Paradoksalnie, obszar ekskluzji społecznej wcale nie musi się kurczyć, a wręcz przeciwnie - może też się rozrastać. Obywatele z jednej strony dostrzegają rozpościerającą się coraz rozleglej, także w skali globalnej, sieć prawa, mającego jakoby zapewnić im bezpieczeństwo, ale z drugiej - tracą też demokratyczna, przedstawicielską kontrolę nad wieloma ważnymi, wcale nie wyłącznie prywatnymi, obszarami regulacji życia, jakie wypełniają oka tej sieci.

Ponadto coraz częściej państwa nie czerpią swojej dominującej legitymizacji z monopolu na legalne użycie siły, nie czerpią jej także $\mathrm{z}$ tonącej w kryzysach gospodarki, więc jeśli przestają być partnerami dla wielkich, bogatych korporacji i tracą władzę nad rynkami, w konsekwencji słabną też politycznie, a władza gospodarcza i polityczna, siła sprawstwa, stopniowo przenosi się prawdopodobnie do korporacji ${ }^{35}$. Ale czy na pewno?

Czy rozproszenie tradycyjnej spójności prawa, kontroli i bezpieczeństwa na różne podmioty, państwowe i prywatne jest objawem słabości instytucji państwa, czy może znaczy coś wręcz odwrotnego: świadomie zatajoną obecność państwa, utajoną władzę działającą "poprzez" instytucje partycypacji?

Czy państwo zachodnie w XXI wieku, szukające dróg odwrotu od opiekuńczości lat 70. XX wieku, powinno teraz zmienić radykalnie strategie działań legislacyjnych? Może powinno, obserwując i monitorując regulacje pozaprawne, spróbować działać mobilniej, jednak wyprzedzać je i konkurować z nimi własnymi aktami? A może zorganizować lepszy nadzór?

Czy oddanie wielu nowych pól aktywności normatywnej oznacza trwałe osłabienie siły sprawczej państwa? A może nie, może to raczej nowy sposób ukrytego sterowania poprzez organizacje pozarządowe? Czy i w jakim zakresie państwo może w ukryty sposób sterować poprzez soft law społeczeństwem? Może oddolna, pełzająca globalizacja wcale nie oznacza rozszerzania zakresu wolności? A może z uwagi na tendencje do oszczędzania i ograniczania funkcji państwa w liberalnych demokracjach - państwo powinno zachować umiar, pogodzić się z ograniczeniem swojej władzy i wykazać rzeczywistą obojętność oraz uznać pełną autonomię podsystemów? Prawdopodobnie czas kapitalizmu państwowego, państwa opiekuńczego, socjalnego, dobiega końca. Konieczna jest więc nowa konceptualizacja badań nad zadaniami państwa. Nie udaje się bowiem na prostej osi:

35 Por. dyskusje o bankructwie Grecji, zbankrutowane miasta w USA itd. 
więcej państwa - mniej państwa wyjaśnić i rozwiązać wielu transnarodowych, globalnych problemów, także prawo w percepcji społecznej nie ma już dostatecznej legitymizacji, charyzmy i siły ${ }^{36}$.

\section{BIBLIOGR AFIA}

Bączyk M., Fojcik-Mastalska E., Góral L., Pisuliński J., Pyzioł W., Prawo bankowe. Komentarz, Warszawa 2003.

Braun T., Charakterystyka zadań $i$ normy tworzone przez funkcję compliance w bankowości - wyzwania rynków regulowanych, „Krytyka Prawa” 2014, nr 6.

Castells M., Siła tożsamości, Warszawa 2009.

Czaputowicz J., Rola państwa w Unii Europejskiej, Warszawa 2004.

Dobrzeniecki K., Autonomiczne prawo cyberprzestrzeni: mit czy rzeczywistość?, [w:] O. Bogucki, S. Czepita (red.), System prawny a porzadek prawny, Szczecin 2008. Dobrzeniecki K., Lex informatica, Toruń 2008.

Dworkin R., Taking Rights Seriously, London 1977.

Foster K., Is there a global sports law? , „Entertainment Law" spring 2003, vol. 2, no. 1. Giddens A., Trzecia droga. Odnowa socjaldemokracji, Warszawa 1999.

Gromski W., Autonomia i instrumentalny charakter prawa, Wrocław 2000.

Jabłońska-Bonca J., Policentryczność źródeł norm w zakresie bezpieczeństwa obywateli.

Problem czy margines?, [w:] S. Lewandowski, H. Machińska, J. Petzel (red.), Prawo, język, logika, Warszawa 2013.

Jabłońska-Bonca J., Prawo powielaczowe, Gdańsk 1986.

Jabłońska-Bonca J., Prawo w kręgu mitów, Gdańsk 1995.

Jabłońska-Bonca J., Tempus Fugit, „,Studies in the Philosophy of Law” 2014, nr 8. Jabłońska-Bonca J., Wymiar sprawiedliwości a przemiany kultury prawnej w Europie,

[w:] W. Morawski (red.), Powiazania zewnętrzne. Modernizacja Polski, Warszawa 2012.

Łętowska E., Multicentryczność współczesnego systemu prawa i jej konsekwencje, „Państwo i Prawo" 2005, nr 4.

Olszak M., Bankowe normy ostrożnościowe, Białystok 2011.

Roach B., Corporate Power in Global Economy, Medford 2007.

\footnotetext{
${ }^{36}$ Na przykład starzenie się społeczeństw nie daje się włączyć w koncepcję „,więcej państwa”, bo oznacza wzrost podatków, a to rodzi ucieczki biznesu do innych państw; nie daje się też włączyć w koncepcję„mniej państwa" bo ludzie starzy jako masowi żebracy na ulicach nie mieszczą się w standardach moralnych i kulturowych społeczeństwa zachodu.
} 
Sousa Santos de B., Toward a New Legal Common sense. Law, Globalization, And Emancipation, London 2002.

Stawecki T., Konwergencja i dywergencja porzadków prawnych w sferze tworzenia prawa, [w:] O. Nawrot, S. Sykuna, J. Zajadło (red.), Konwergencja czy dywergencja kultur i systemów prawnych?, Warszawa 2012.

Szewczyk O., Odpowiedzialność, „,Wprost”, 1.08.2012.

Szwarc A. (pr. zbior. red.), Kompatybilność pozaprawnych regulacji sportowych z regulacjami prawnymi, Poznań 2014.

Teubner G., Recht als autopoietisches System, Frankfurt am Main 1989.

Teubner G., Wilke H., Dezentrale Kontextstreuerung in Recht intermediarer Verbande, [w:] G. Teubner, H. Wilke, Kontext und Autonomie, „Zeitschrift fur Rechtssoziologie" 1984, vol. 1.

Torre M.A., Legal pluralism as evolutionary achievement of community law, „Ratio Iuris" 1999, vol. 12, no. 2.

Wielecki K., Kryzys i socjologia, Warszawa 2012.

Winczorek J., Pluralizm prawny wczoraj i dziś. Kilka uwag o ewolucji pojęcia, [w:] D. Budnikowski, K. Dobrzeniecki (red.), Pluralizm prawny, Toruń 2009. Wróblewski J., Nieostrość systemu prawa, „Studia Prawno-Ekonomiczne” 1983, t. XXXI. 